\title{
THE IMPACT OF THE SOCIAL ON THE HOME COMPUTER
}

\section{Lynne Baillie}

Telecommunication Research Center, Vienna, Austria.

\begin{abstract}
Why do some technologies successfully assimilate into the home and others fail? The physical layout could be one factor but another more important factor could be the social aspects of the home space. Also, once a technology enters the home does it impact on the social life of that home? Some manufacturers in the past have adapted their devices so that they assimilate more clearly into the home, however, until quite recently this was something that was not done by manufacturers of PCs. The impact that this design decision has had on the acceptance of the home computer is the topic of this paper.
\end{abstract}

Key words: domestic technology, design decisions, acceptance.

\section{INTRODUCTION}

This paper investigates the findings of studies on the use of the PC in the home, this is important as the background research provides a rationale as to why the PC for a long time was not assimilated into the social aspects of the home. The first section reports on some early studies of the adoption and use of computers in the home and then explores whether the PC has ever really become a 'home' computer in the broadest sense. The importance the advent of the Internet has had on the home computer is then discussed. The paper concludes with a short discussion of what implications these findings may have for the new more entertainment orientated PC's currently being proffered for the home. 
2. THE HOME COMPUTER AND THE INTERNET

\subsection{A Brief History of the Home Computer}

Home computers were sold to people in the 1980 s as a way of working at home, to help educate children, for word processing, and generally equipping yourself and your children for the future. However, enthusiasm for this idea levelled off. Researchers found that some of the reasons for this were that there was not a functional need for a computer in the home (except for a small minority of people), the word-processing function could be equally well performed by an expensive typewriter or dedicated word processor, and the video games function could be fulfilled more cheaply by a home video game machine (Caron, 1985). Because of this the families that had bought computers in the 1980 s failed to trade-up to more sophisticated models, when they became available on the market e.g. Amstrad's PCW IBMs home computer, BBC Micro, Sinclair Spectrum and Dragon 32. Murdock, Hartmann and Gray (1992) thought that early disillusionment had affected the views of householders. A quote from one of the householders they interviewed:

'I wanted it as a word processor, but of course its no good for that at all. I didn't appreciate it at the time. You can't get enough words on the screen, unless you get one that's about four or five times the price...I wanted it for a word processor and they said (the shop assistants), "Oh yes they can do this" and "Oh yes they do that", you know. And of course it does, but not satisfactorily for proper use.' (Murdock et al. 1992, p.148)

This quote clearly highlights why people were disillusioned with the early computers they bought, as the PC quite singularly failed to live up to the marketing hype and was not robust enough to perform the tasks that were required of it e.g. word processing. Another reason for failure was highlighted by Silverstone et al (1992). They commented that computers had failed to find a place within the moral economy of the household, specifically in terms of its incorporation into the routines of daily life. This failure is discussed in the next section.

\subsection{The 'Home' Computer}

One of the comments made about PCs in the home is that they have failed to be completely assimilated into that environment (Venkatesh, 1996; Silverstone et al., 1992). The look of a PC could be one reason why the PC bought for the home place has, until quite recently with the advent of iMacs, failed to be assimilated into the home as the PC in the home-place has 
looked no different from the PC in the workplace. PC manufacturers have not until quite recently acted in the same way as Singer (see Section 3) and try to redesign or remodel the $\mathrm{PC}$ so that it would be better assimilated into the home. The PC in the 1980's and 90's was still in the main a stand-alone unit that had come from an industrial/business background, and unlike other technologies in the home, had not been specifically built to carry out a task in the home e.g. cleaning floors. Some researchers suggested in the 1980s that the reason for this is that the PC is too complex a machine for the home. Rubin commented that unlike other technologies in the home:

'Learning to use a computer is much more like taking up a musical instrument than following instructions on how to use an electrical appliance, such as a toaster.' (Rubin, August, 1983).

However, research carried out at that time and since has suggested that people do not use their PCs in complex ways, for example, Caron (1985) found that people in the home only used their PC for word processing and games. Similarly in the 1990's Kraut (1996) found that people mainly used their PCs for games and email. Their research suggests that people use and have historically used their PCs in the home in quite straightforward and uncomplicated ways. Therefore, it cannot be assumed, that just because people are using a complex machine they are using it in a complex way. It could be concluded then that the poor assimilation of the PC into the home cannot completely be blamed on the complexity of the machine.

A possible alternative suggestion, as to why the $\mathrm{PC}$ has experienced poor assimilation, is that people in the home are unsure of where to place it. During their research, the team at CRITO (Center for Research on Information Technology and Organizations), found that in the 1980s the personal computer, although in the home, had not become a 'home computer' and had not been integrated into the home in the social context. They thought that there might be several possible reasons for this: people viewed their home computer as an extension of their work computer; software for home use was not well developed; no telecommunications connectivity; inapplicability and inappropriateness of the industrial/business model for the household; and a lack of computer skills amongst the general public. Subsequently, the adoption of PCs grew quickly in the late 1990s, according to Venkatesh because there was a new generation of young adults who grew up with PCs, more manufacturers targeted their software towards the home market, and most importantly PCs had acquired communication capabilities. The importance of these new communication capabilities are of critical importance when one comes to consider the PC in the home as a social facilitator. 


\subsection{The Impact of the Internet on Home PCs}

The impact of the Internet on home computers cannot be underestimated. However, Kraut (1996) thought that this marketing of these new internet capabilities was flawed. He compares this with how the telephone was at first marketed for business use and then later in the home:

'Manufacturers of the telephone did not foresee that many different types of people would like to talk on the phone for its own sake and not to accomplish a task, but because they enjoyed talking to other people.' (Kraut, 1996, p34).

He comments that how banks, phone companies, and computer companies insisted on selling computers and online services to consumers for telecommuting, home banking, and home shopping, seemed to echo the early misunderstanding of the use of the telephone. The main use of the telephone was in fact for personal communications, this has also been found to be the main use of the Internet in the home (Kraut, 1996). Venkatesh (1996) made a similar finding commenting that business people stress the mass media features of the Internet and its ability to broadcast information, entertainment, and advertisements to a large population of consumers. In contrast, people at home value the Internet for more personal uses to maintain social relationships and to participate in their local communities. However, even with these new telecommunication capabilities the home PC still failed to permeate homes in the same way as television and the telephone. In the next section I discuss how it could be another issue that of the look and design of the PC itself could have had a major impact on the social acceptance of the PC in the home.

\section{RE-DESIGNING FOR SOCIAL ACCEPTANCE}

The sewing machine is an interesting case of when a manufacturer completely changed the look of the machine so that it would be accepted in the home. Sewing machine manufacturers in the mid 1800's were faced with a massive drop in industrial sales. A possible market that had not been sold to before was the home. It became an economic necessity, therefore, to turn the sewing machine into a domestic appliance, but this was easier said than done. Initial attempts were not too successful, mainly because the industrial connotations had not been removed. The manufacturers realised that unless they created the impression that the place for a sewing machine was in the home, the market was never going to accept the machine. The manufacturers did not try to redesign the sewing machine but merely place it in their 
marketing literature in the setting of a parlour. These adverts, however, did not convince people to buy. Because as Forty (1986) commented having these sewing machines in your home would be like having a machining tool in your living-room. One manufacturer (Singer), however, decided to go a step further than the others and design the machine to fit into the home setting. They did this by making the machine smaller in size, lighter in weight, and giving it a more elegant design. This led to massive sales and to the acceptance of the sewing machine in the home.

It could be concluded from this that computer manufacturers in the $1980 \mathrm{~s}$ and 1990s failed to do what Singer did and redesign the PC to fit into the social space of the home. How some manufacturers are aiming to change that is discussed in the next section.

\section{THE FUTURE FOR THE PC AND OTHER TECHNOLOGIES IN THE HOME}

Mackay carried out a study of people's acquisition of the following devices: telephone, television, videocassette recorder (VCR), home computer, computer games console, and compact disc (CD) player. He was interested in these technologies because he thought that they were becoming more and more connected and inextricably linked. He concluded from his studies that there is a growing demand for interactivity between PCs, games consoles, and CD-Players. Recently, the mobile telephone has been added to this list. The scale and significance of this shift should not be underestimated he said because in recent years the video game has superseded popular music as the main form of entertainment:

'Far from being a marginal arena, the home is a key location for our experience of IT, and for the success (or otherwise) of specific IT products. Domestic leisure as we now know it is inconceivable without an extensive range of IT devices. Rather than being marginal, or 'not real

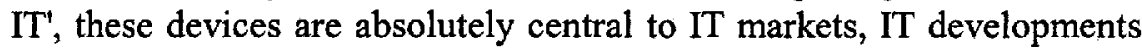
and our daily experience of IT.' (Mackay, 1995, p267).

Ted Turner - CEO of cable news network- made the following comment about interactive television:

'Every single interactive TV experiment has failed. Most people want to sit back and watch- interacting is hard work'. (Ted Turner, 1994, p3).

So do we want to interact in new ways with our devices? It would seem in the case of interactive television, that we do not, in a report by Towler (2001) for the Independent Television Commission, it was reported that $80 \%$ 
of the people with digital televisions said that they never or only rarely used any of the interactive services and that they had in fact bought the TVs because of the improvements in sound and picture quality. So we do not seem to want to interact more with our televisions and our PCs are being left to gather dust.

One technology firm has tackled this issue by marketing their entertainment PC as a television first: "The PC to replace your television" (Sony, 2005). It would seem that Sony are following the path forged by Singer's (see previous section) and re-designing the PC to fit more comfortably into the home space as Jun Koyama (2004) from Sony comments:

"Our new PCs are for people who don't want to see PC as a beige box in the corner of their living room that performs a useful but essentially dull service. It is intended to sit centre stage, and act as an entertainment system."

This approach though could be problematic in the home as it means that what were three-four separate devices are now contained in one unit. Researchers have criticised this approach as they say that these new systems containing one large display ignores the fact that physical materials and technologies are currently distributed throughout the home to suit that particular household's lifestyle (Graves-Petersen, 2004). Furthermore people are wary of so much technology being contained within one device, as this would mean that if the system broke down they would not only be without their television but also their computer, games console and sound system. Another hurdle to overcome in the immediate future is the lack of standard communications between devices from different manufacturers.

However, there is a demand for ever more linked up technology and interactivity and these technologies will be combining the power of a computer with the latest communication technology. At the moment, however, it would seem that the user is not being consulted on the design and functions of these newly minted technologies and may well be left as the outsider. An improved approach to the field of dreams (i.e. if we build it they will come) would be if manufacturers and designers tried to understand:

- What technologies people want to be able to connect together and when?

- The level of interactivity they want.

- How to provide these services via the device (perhaps through the infrastructure of the web). 


\section{CONCLUSION}

At the moment mergers are taking place of several technology sectors e.g. computers, telecommunications, broadcast and cable television. To facilitate this merger and to make the new devices and services financially viable, manufacturers 'need' people to use these new interactive devices and services in their homes. This requires users to interact with their devices in new ways e.g. carry out their banking via their television, or ordering food on-line via their microwave. It could be strongly argued given the research outlined in this paper that the very fact that these devices are in peoples homes is not enough in of itself to guarantee that people will use them in the way that manufacturers want and crucially 'need' them to use them. This may then be the perfect time to study once again our relationship with the home PC and other home technologies as our relationship with these technologies is set to become more complex with the advent of digital television, home media centres, and hybrid telephones.

\section{REFERENCES}

Campbell, C. (1992) The Desires for the New: Its Nature and Social Location as Presented in Theories of Fashion and Modern Consumerism. In R. Silverstone., \& E.Hirsch (Eds.) Consuming Technologies: Media and Information Spaces.(p.54-65).London: Routledge.

Caron, A.H. (1985) The Process of Microcomputers in the Home: Uses and Impacts. Montreal Universite de Montreal. Departmente de Communication. Unpublished Paper.

Corrigan. P (1997) The Sociology of Consumption. London: Sage

Csikszentmihalyi, M., \& E. Rochberg-Halton (1981) The Meaning of Things: Domestic Symbols and the Self. New York: Cambridge University Press.

Forty, A. (1986) Objects of Desire: Design and Society Since 1750. London: Thames \& Hudson.

Graves-Petersen, M. (2004) Remarkable Computing- the Challenge of Designing for the Home.

Johnson, S. (1997) Interface Culture: How New Technology Transforms the Way We Create and Communicate. New York: Basic Books.

Kraut, R. (1996). The Internet@ Home. ACM, 39 (12): 32-35.

Koyama, J (2004) http://www.sony-europe.com/PageView.do?site=odw_en_EU\&page= PressReleaseDetail\&section=en_EU_Press\&pressrelease $=1094201879226$

Miles, I., Cawson, A., \& Haddon, L. (1992) The Shape of Things to Consume. In R. Silverstone., \& E.Hirsch (Eds.) Consuming Technologies: Media and Information Spaces. (p. 66-83) London: Routledge.

Mackay, H. (1995) IT and the Home. In N. Heap., R. Thomas., G. Einon., R.Mason., \& H.Mackay (Eds.) Information Technology and Society: A Reader. (p. 267-311) London: Sage.

Murdock, G., Hartmann, P., \& P.Gray. (1992) Contextualising Home Computing: Resources and Practices. In R. Silverstone., \& E. Hirsch (Eds.) Consuming Technologies: Media and Information in Domestic Spaces. (p. 146-162) London: Routledge. 
Norman, D. (1999) The Invisible Computer. London: MIT Press.

Silverstone, R., Hirsch, E., \& Morley, D. (1992) Information and Communication Technologies and the Moral Economy of the Household. In R. Silverstone \& E. Hirsch (Eds.) Consuming Technologies: Media and Information in Domestic Spaces. (p.15-30) London: Routledge.

Sony (2005): http://www.sonystyle.com

Towler, R (2001) The Public's View 2001. An ITC/BSC Research Publication. http://www.itc.org.uk/itc_publications/index.asp (last checked 19/07/2002).

Turner, T. (1994) What if they're right? The Economist. Feb 12, p3.

Venkatesh, A., \& Vitalri, N. (1986) Computing Technology for the Home: Product Strategies for the Next Generation. Journal of Product Innovation and Management, 3(1), 171-186.

Venkatesh, A. (1996) Computers and other interactive technologies for the home. ACM, 39 (12), 47-54. 